\title{
Bread-making properties of rice bread added with naked oat flours
}

\author{
Hyun-Il Jun ${ }^{1}$, Sun-Hee Yoo ${ }^{2}$, Geun-Seoup Song ${ }^{1}$, Young-Soo Kim ${ }^{1 *}$ \\ ${ }^{1}$ Department of Food Science and Technology, Chonbuk National University, Jeonju 54896, Korea \\ ${ }^{2}$ Agricultural Technology Center, Jeongeup 56141, Korea
}

\section{쌀귀리를 첨가한 쌀식빵의 제빵적성}

\author{
전현일 ${ }^{1} \cdot$ 유선희 ${ }^{2} \cdot$ 송근섭 ${ }^{1} \cdot$ 김영수 $^{1 *}$ \\ 1전북대학교 식품공학과, ${ }^{2}$ 정읍시 농업기술센터
}

\begin{abstract}
This study was carried out to investigate the bread-making properties of rice bread added with naked oat flours $(0-15 \%)$. The water, crude protein, crude lipid, and crude ash contents of the rice flour used to prepare the rice bread were 11.8, 8.6, 1.8, and $1.3 \%$, respectively, and the contents of total starch, amylose, damaged starch, and dietary fiber contents were $75.7,23.1,30.0$, and $1.7 \%$, respectively. The crude protein, crude lipid, and crude ash increased, whereas total starch, amylose, and starch damage decreased with increasing addition of naked oat flour in the rice-naked oat composition flour (RNOCF). The pasting properties of RNOCF showed a slight decrease in peak viscosity, trough, final viscosity, and setback with increasing addition of naked oat flour. As the fermentation time increased, the $\mathrm{pH}$ of RNOCF dough added with naked oat flour decreased, whereas its expansion ratio significantly increased. The volume, specific volume, and baking loss ratio of the rice bread decreased for 10 and $15 \%$ addition, compared to 0 and $5 \%$ addition. With increasing addition of naked oat flour, the hardness of rice bread increased, whereas the cohesiveness and springiness were not significantly affected. Results indicated that rice bread added with $5 \%$ naked oat flour had the best quality.
\end{abstract}

Key words : bread-making properties, rice bread, naked oat flour, rice-naked oat composition flour, pasting property

\section{서 론}

벼과(Gramineae)에 속하는 귀리(Avena sativa L.)는 종실 에 붙어있는 껍질의 유무에 따라 껍질이 붙어 있는 겉귀리 와 껍질이 분리된 쌀귀리로 구분된다. 주로 식용으로 사용 되는 쌀귀리는 겉귀리에 비해 겉껍질을 제거할 필요가 없고 단백질 함량이 높을 뿐만 아니라 수용성식이섬유를 많이 함유하고 있어 다른 곡류들에 비해 영양학적으로 우수한 작물로 인정을 받고 있다(1). 귀리는 다른 곡류에 비해 수용 성식이섬유 일종인 $\beta$-glucan을 다량 함유하고 있어 혈중

*Corresponding author. E-mail : ykim@jbnu.ac.kr Phone : 82-63-270-2569, Fax : 82-63-270-2572

Received 8 October 2018; Revised 26 November 2018; Accepted 26 November 2018.

Copyright (c) The Korean Society of Food Preservation. All rights reserved.
콜레스테롤함량을 저하시킬 뿐만 아니라 당류의 소화흡수 를 억제하여 혈당농도를 낮추는 것으로 알려져 있다. 또한, 대장암 예방 및 면역력 증가 등 다양한 생리기능(2-4)을 가지고 있는 것으로 보고되었다. 특히, 타임지가 선정한 10 대 건강식품에 포함되면서 많은 사람들의 관심을 불러 일으켜 소비가 급격히 증가하고 있지만 현재까지는 주로 oatmeal이나 flake 형태로 아침식사 대용으로 소비되고 있 어 다양한 종류의 귀리 가공식품이 요구되고 있다.

쌀은 대부분이 밥의 형태로 이용되고 있으나 식생활의 서구화 및 간편화와 인구감소로 인하여 소비가 지속적으로 감소하고 있는 상황으로 쌀의 소비확대를 위해서는 다양한 종류의 쌀 가공식품이 개발되어야 한다. 현재 쌀을 이용한 가공식품으로는 떡류와 즉석밥을 비롯하여 주류가 주를 이루고 있는데, 최근에는 건강에 대한 관심의 증가로 기능 성이 확인된 잡곡류를 비롯하여 많은 식물성 천연소재를 활용한 가공제품의 개발 연구가 강조되고 있다. 더욱이 쌀 
의 소비량이 감소하고 있는 상황에서 귀리와 쌀을 이용한 빵을 개발한다면 국내에서 생산되는 귀리와 쌀의 소비확대 에도 도움이 될 것으로 판단된다. 특히, 귀리는 쌀에 비해 단백질 함량이 높을 뿐만 아니라 좋은 영양가를 나타내는 아미노산 조성을 가지고 있어 쌀과 함께 섭취하기 적합하 며, 품종별로는 껍질이 없는 쌀귀리가 도정이 필요 없는 장점이 있어서 가공제품을 개발하는데 유리하다(5-7).

따라서 본 연구에서는 쌀귀리 품종 중 하나인 조양 (Choyang)의 활용성을 높이고 쌀의 소비를 촉진시키기 위 한 방안으로 쌀식빵을 제조하기에 적합한 쌀귀리 첨가량과 이를 이용하여 제조한 쌀식빵의 제빵적성을 조사하였다.

\section{재료 및 방법}

\section{실험재료}

쌀귀리 가루는 전북 정읍에서 생산된 조양 품종을 열풍 건조하여 수분함량을 $12 \%$ 로 조절한 후에 제분기(single type stainless roller, Shinpoong Eng. Ltd, Gwangju, Korea)로 분말화하여 사용하였다. 쌀식빵 제조에 사용된 쌀가루 (Daedoofood Co., Gunsan, Korea), 이스트(S.I.Lesaffre, Marcq, France), 제빵개량제(Shinwangfood Co., Gimhae, Korea), 탈지분유(Seoulmilk, Yangju, Korea), 설탕(Samyang Co., Ulsan, Korea), 천일염(Doyoumwon Co., Ansan, Korea), 마가린(Lottefood Co., Cheonan, Korea), 계란(Join Co., Yongin, Korea) 및 활성글루텐(Singsongfood Co., Nonsan, Korea) 등은 마트에서 구입하여 사용하였다.

\section{혼합쌀 가루의 일반성분 및 탄수화물 분석}

일반성분 함량은 $\mathrm{AOAC}$ 법(8)을 이용하여 수분은 상압가 열건조법, 조회분은 직접회화법, 조지방은 Soxhlet법, 그리 고 조단백질은 Micro-Kjeldahl법으로 측정하였다.

총전분 함량은 Megazyme total starch assay kit(Megazyme Pty., Ltd., Wicklow, Ireland)를 사용하여 McCleary 등의 방 법(9)으로 측정하였다. 아밀로스 함량은 Brand-Williams 등 의 방법(10)을 응용하여 $680 \mathrm{~nm}$ 에서 흡광도(UV-1650PC, Shimadzu Co., Kyoto, Japan)를 측정하였으며, 손상전분 함 량은 Boyaci 등의 방법(11)을 사용하여 측정하였다. 총 식이 섬유 함량은 Prosky 등의 방법(12)으로, 그리고 $\beta$-glucan 함량은 McCleary와 Glennie-Holmes의 방법(13)으로 측정 하였다.

\section{혼합쌀 가루의 호화특성}

호화특성은 Jun 등(14)이 사용한 방법으로 측정하였다. 즉, 시료 $(3.5 \mathrm{~g})$ 에 증류수 $(25 \mathrm{~mL})$ 를 첨가하여 잘 혼합한 후에 RVA(RVA-4, Newport Scientific pty. Ltd., Warriewood, Australia)를 사용하여 측정하였다. 측정을 위해 사용된 온
도는 0-1.0분에서 $50^{\circ} \mathrm{C}$ 유지, $1.0-4.8$ 분에서 $95^{\circ} \mathrm{C}$ 까지 가열, 4.8-7.3분에서 $95^{\circ} \mathrm{C}$ 유지, 7.3-11.01분에서 $50^{\circ} \mathrm{C}$ 까지 냉각, 그리고 11.01-12.05분에서 $50^{\circ} \mathrm{C}$ 를 유지하였다. 호화특성은 $\mathrm{RVA}$ 측정결과로 얻어진 최고점도, 최저점도, 최종점도, 강하점도와 치반점도로 나타내었으며, 강하점도는 최고점 도에서 최저점도를 뺀 값으로, 치반점도는 최종점도에서 최저점도를 뺀 값으로 하였다.

\section{혼합쌀 가루 반죽의 물리적 특성 분석}

반죽의 $\mathrm{pH}$ 와 팽창률은 $\mathrm{Kim}$ 등(15)의 방법을 응용하여 측정하였다. 반죽의 $\mathrm{pH}$ 는 완성된 반죽 $5 \mathrm{~g}$ 에 증류수 45 $\mathrm{mL}$ 를 넣고 2분 동안 충분하게 균질(homogenizer DIAX 600, Heidolph, Kelheim, Germany)한 혼탁액을 $\mathrm{pH}$ meter (SevenMulti, Mettler Toledo GmBH, Giessen, Germany)로 측정하였다. 이때, 완성된 반죽은 2 시간 동안 30 분 간격으 로 측정하였다.

반죽의 팽창률은 완성된 반죽 $10 \mathrm{~g}$ 을 $50 \mathrm{~mL}$ 메스실린더 에 넣고 $27^{\circ} \mathrm{C}$ 에서 2시간 동안 발효(LBI-250M, Daeyonng Bakery Machinery Co., Ltd., Seoul, Korea)하면서 30분 간격 으로 증가된 부피를 측정하였다. 이때, 반죽의 초기 부피는 $9 \mathrm{~mL}$ 로 동일하게 조절하였다.

\section{쌀식빵 제조}

쌀식빵 제조를 위한 기본 배합비는 예비실험을 통하여 쌀가루 $1,100 \mathrm{~g}$, 드라이이스트 $22 \mathrm{~g}$, 제빵개량제 $11 \mathrm{~g}$, 탈지 분유 $33 \mathrm{~g}$, 설탕 $66 \mathrm{~g}$, 천일염 $22 \mathrm{~g}$, 마가린 $88 \mathrm{~g}$, 계란 55 $\mathrm{g}$, 활성글루텐 $25 \mathrm{~g}$, 물 $638 \mathrm{~g}$ 을 설정하였다. 쌀귀리 첨가량 별 쌀식빵 제조에 사용된 혼합쌀 가루는 쌀가루 중량 $(1,100$ $\mathrm{g}$ 기준)의 0-15\%를 쌀귀리 가루로 대체하여 제조하였다. 쌀식빵 제조에 사용되는 재료 중에서 마가린을 제외한 모든 재료를 계량하여 반죽기(BNVM-12, Daeyonng Bakery Machinery Co., Ltd.)에 넣고 반죽한 후에 클린업 단계에서 마가린을 첨가하여 반죽을 완성하였다. 이때 반죽의 최종 온도는 $29 \pm 0.5^{\circ} \mathrm{C}$ 로 하였다. 완성된 반죽은 $167 \mathrm{~g}$ 씩 분할하 여 둥글리기를 하고 상온에서 10 분 동안 휴지한 후 밀대로 밀어서 가스빼기를 하였다. 이후에 말아서 성형하여 식빵 팬(위; $8.4 \times 19.1 \times 9.6 \mathrm{~cm}$, 아래; $8.4 \times 19.1 \times 9.6 \mathrm{~cm}$ )에 삼봉형 으로 넣었다. 반죽이 들어있는 식빵팬은 발효기(FP-201, Daeyonng Bakery Machinery Co., Ltd.)에서 약 40-45분 동안 발효(온도 $38^{\circ} \mathrm{C}$, 상대습도 $80 \%$ )한 후에 윗불과 아랫불이 각각 $160^{\circ} \mathrm{C}$ 와 $200^{\circ} \mathrm{C}$ 로 예열된 전기오븐(FDO-7013, Daeyonng Bakery Machinery Co., Ltd.)에 넣고 40분 동안 구워 쌀식빵 을 제조하였다.

\section{쌀식빵의 무게, 부피, 비용적 및 굽기 손실률}

쌀식빵의 무게, 부피, 비용적 및 굽기 손실률은 Ko 등(16) 의 방법을 응용하여 측정하였다. 제조된 쌀식빵의 무게, 
부피, 비용적, 굽기 손실률은 상온에서 90 분 동안 방랭하여 식힌 후에 분석시료로 사용하였다. 무게 $(\mathrm{g})$ 는 전자저울 (EB-2200HX-D, Shimadzu Co., Kyoto, Japan), 부피 $(\mathrm{mL})$ 는 조를 이용한 종자치환법으로 측정하였다. 식빵의 비용적 $(\mathrm{mL} / \mathrm{g})$ 은 쌀식빵의 부피를 쌀식빵의 무게로 나누어 구하였 고, 굽기 손실률은 쌀식빵 한 개에 사용된 반죽의 무게와 측정된 쌀식빵의 무게를 이용하여 굽기 전과 구운 후의 중량차이로 산출하였다.

Baking loss ratio $(\%)=\frac{(\mathrm{B}-\mathrm{A})}{\mathrm{A}} \times 100$

이때, $\mathrm{A}$ 는 쌀식빵의 무게 $(\mathrm{g}), \mathrm{B}$ 는 반죽의 무게 $(\mathrm{g})$ 이다.

\section{쌀식빵 속질의 색도 및 조직감}

제조된 쌀식빵은 상온에서 90 분 동안 방랭하여 식힌 후 에 슬라이서(BSC-T13, Daeyung Bakery Machinery Co., Ltd.)를 사용하여 $13 \mathrm{~mm}$ 두께로 잘랐으며, 슬라이스 중에 높이가 가장 높은 두 장을 겹쳐서 쌀식빵 속질(crumb)의 색도 및 조직감의 분석시료로 사용하였다.

색도는 색차계(SP-80, Tokyo Denshoku, Tokyo, Japan)를 사용하여 $\mathrm{L}$ (명도), $\mathrm{a}$ (적색도), $\mathrm{b}$ (황색도) 값을 측정하였다. 조직감은 직경 $36.0 \mathrm{~mm}$ compression probe가 장착된 Texture analyzer(TA-XT2i, Stable Micro systems Co., Ltd., Surrey, $\mathrm{UK}$ )를 사용하여 경도, 응집성, 탄성, 검성 및 씹힘성 을 측정하였다. 분석조건은 texture profile analysis mode에 서 load cell은 $5 \mathrm{~kg}$, pretest speed는 $1.0 \mathrm{~mm} / \mathrm{s}$, test speed는 $1.7 \mathrm{~mm} / \mathrm{s}$, post test speed는 $10.0 \mathrm{~mm} / \mathrm{s}$, strain은 $40 \%$ 이었다.

\section{통계분석}

각 실험에서 3회 반복(조직감은 5 회 반복)하여 얻은 결과 를 SAS 통계프로그램(Version 9.1, SAS Institute, Cary, NC, USA)을 사용하여 평균과 표준편차로 나타내었다(17). 각 시료간 유의성은 $\mathrm{p}<0.05$ 수준에서 one way ANOVA로 분산 분석한 후에 Duncan's multiple range test로 비교하였다.

\section{결과 및 고찰}

쌀귀리 가루 첨가량에 따른 흔합쌀 가루의 물리화학적 특성

쌀귀리 가루 첨가량별 혼합쌀 가루의 물리화학적 특성은 Table 1과 같다. 쌀귀리 가루가 첨가되지 않은 쌀가루의 수분, 조단백질, 조지방 및 조회분 함량은 각각 $11.8,8.6$, 1.8 및 $1.3 \%$ 를 나타내었다. 쌀가루의 탄수화물 조성은 총 전분, 아밀로스, 손상전분 및 총식이섬유 함량이 각각 75.7 , $23.1,30.0$ 및 $1.7 \%$ 이었으나 $\beta$-glucan 함량은 측정되지 않았 다. 이는 기존에 보고된 국내산 멥쌀 품종의 수분(8-13.8\%), 아밀로스(10.0-21.6\%) 및 손상전분(6.2-17.2\%) 함량에 비해 수분함량은 유사하였으나 아밀로스와 손상전분이 다소 높 았다(18).

쌀귀리 가루 첨가량을 $5 \%$ 에서 $15 \%$ 까지 증가시킨 혼합 쌀 가루는 수분이 $11.5 \%$ 에서 $11.1 \%$, 총 전분이 $74 \%$ 에서 $72.5 \%$, 아밀로스가 $22.8 \%$ 에서 $22.2 \%$, 손상전분이 $28.9 \%$ 에 서 $27.0 \%$ 로 감소하였으나, 조단백질이 $9.2 \%$ 에서 $10.8 \%$, 조지방이 $2.1 \%$ 에서 $2.7 \%$, 조회분이 $2.1 \%$ 에서 $2.7 \%$, 총 식

Table 1. Physicochemical properties of rice-naked oat composition flour

\begin{tabular}{|c|c|c|c|c|c|}
\hline \multirow{2}{*}{\multicolumn{2}{|c|}{ Components }} & \multicolumn{4}{|c|}{ Naked oat flour substitution (\%) } \\
\hline & & 0 & 5 & 10 & 15 \\
\hline \multicolumn{2}{|r|}{ Moisture (\%) } & $11.8 \pm 0.2^{\mathrm{al})}$ & $11.5 \pm 0.1^{\mathrm{a}}$ & $11.2 \pm 0.1^{b}$ & $11.1 \pm 0.1^{b}$ \\
\hline \multicolumn{2}{|r|}{ Crude protein $(\%)$} & $8.6 \pm 0.1^{\mathrm{c}}$ & $9.2 \pm 0.2^{\mathrm{b}}$ & $10.3 \pm 0.8^{\mathrm{a}}$ & $10.8 \pm 0.1^{\mathrm{a}}$ \\
\hline \multicolumn{2}{|r|}{ Crude lipid (\%) } & $1.8 \pm 0.0^{\mathrm{d}}$ & $2.1 \pm 0.1^{\mathrm{c}}$ & $2.3 \pm 0.0^{b}$ & $2.7 \pm 0.1^{\mathrm{a}}$ \\
\hline \multicolumn{2}{|r|}{ Crude ash (\%) } & $1.3 \pm 0.0^{c}$ & $1.5 \pm 0.0^{\mathrm{b}}$ & $1.7 \pm 0.0^{\mathrm{a}}$ & $1.8 \pm 0.1^{\mathrm{a}}$ \\
\hline \multirow{5}{*}{ Carbohydrate } & Total starch (\%) & $75.7 \pm 0.7^{\mathrm{a}}$ & $74.0 \pm 0.2^{b}$ & $73.5 \pm 0.4^{b}$ & $72.5 \pm 0.1^{\mathrm{c}}$ \\
\hline & Amylose $(\%)$ & $23.1 \pm 0.1^{\mathrm{a}}$ & $22.8 \pm 0.1^{b}$ & $22.6 \pm 0.1^{\mathrm{c}}$ & $22.2 \pm 0.1^{\mathrm{d}}$ \\
\hline & Starch damage $(\%)$ & $30.0 \pm 1.1^{\mathrm{a}}$ & $28.9 \pm 0.2^{\mathrm{a}}$ & $27.8 \pm 0.2^{\mathrm{b}}$ & $27.0 \pm 0.3^{\mathrm{c}}$ \\
\hline & Total dietary fiber (\%) & $1.7 \pm 0.2^{\mathrm{d}}$ & $2.1 \pm 0.1^{\mathrm{c}}$ & $2.8 \pm 0.1^{\mathrm{b}}$ & $3.0 \pm 0.1^{\mathrm{a}}$ \\
\hline & $\beta$-Glucan (\%) & $\mathrm{ND}^{2)}$ & $0.3 \pm 0.0^{c}$ & $0.5 \pm 0.1^{\mathrm{b}}$ & $0.8 \pm 0.1^{\mathrm{a}}$ \\
\hline \multirow{5}{*}{ Pasting property3) } & Peak viscosity (RVU) & $245.2 \pm 1.1^{\mathrm{a}}$ & $241.0 \pm 0.1^{b}$ & $238.0 \pm 1.1^{\mathrm{c}}$ & $235.7 \pm 0.6^{\mathrm{d}}$ \\
\hline & Trough (RVU) & $141.0 \pm 1.5^{\mathrm{a}}$ & $140.0 \pm 0.5^{\mathrm{a}}$ & $136.7 \pm 0.8^{b}$ & $135.1 \pm 0.5^{\mathrm{c}}$ \\
\hline & Final viscosity (RVU) & $235.2 \pm 1.3^{\mathrm{a}}$ & $229.8 \pm 0.7^{b}$ & $227.9 \pm 0.1^{\mathrm{c}}$ & $221.9 \pm 0.5^{\mathrm{d}}$ \\
\hline & Break down (RVU) & $104.2 \pm 0.5^{\mathrm{a}}$ & $101.0 \pm 0.4^{\mathrm{b}}$ & $101.3 \pm 0.3^{b}$ & $100.6 \pm 0.1^{b}$ \\
\hline & Setback (RVU) & $94.2 \pm 0.3^{\mathrm{a}}$ & $89.8 \pm 1.2^{b}$ & $91.2 \pm 0.7^{b}$ & $86.8 \pm 1.0^{c}$ \\
\hline
\end{tabular}

\footnotetext{
${ }^{1)}$ Values are mean $\pm \mathrm{SD}(\mathrm{n}=3)$. Different small letters ${ }^{(a-d)}$ in the same row are significantly different by Duncan's multiple test $(\mathrm{p}<0.05)$.
}

${ }^{2)} \mathrm{ND}$ is an abbreviation for not detected.

${ }^{3}$ Break down value is a difference between peak viscosity and trough, setback value is a difference between final viscosity and trough 
이섬유가 $2.1 \%$ 에서 $3.0 \%, \beta$-glucan이 $0.3 \%$ 에서 $0.8 \%$ 로 증 가하여 쌀귀리 가루 첨가량이 증가할수록 수분을 제외한 일반성분과 비전분다당류는 증가한 반면에 전분과 관련된 성분은 감소하는 것으로 나타났다. 이는 이전 연구에서 보 고한 쌀귀리 가루가 쌀가루에 비해 수분, 총 전분, 아밀로스 및 손상전분의 함량이 낮은 반면, 조단백질, 조지방, 조회분, 총 식이섬유 및 $\beta$-glucan 함량이 높았기 때문으로 추정된다 (14).

쌀가루의 호화특성은 최고점도가 $245.2 \mathrm{RVU}$, 최저점도 가 $141.0 \mathrm{RVU}$, 최종점도가 $235.2 \mathrm{RVU}$, 강하점도가 104.2 $\mathrm{RVU}$, 그리고 치반점도가 $94.2 \mathrm{RVU}$ 로 높은 강하점도와 치반점도 값을 나타내어 멥쌀가루의 호화특성 양상을 보였 다. 쌀귀리 가루 첨가량을 $5 \%$ 에서 $15 \%$ 까지 증가시킨 혼합 쌀 가루의 최고점도는 241.0 에서 $235.7 \mathrm{RVU}$, 최저점도는 140.0 에서 $135.1 \mathrm{RVU}$, 최종점도는 229.8 에서 $221.9 \mathrm{RVU}$, 그리고 치반점도는 89.8 에서 $86.8 \mathrm{RVU}$ 로 소폭 감소하는 경향을 나타내었다. 그러나 강하점도는 101.0에서 100.6 $\mathrm{RVU}$ 로 유의적 차이가 없어 쌀귀리 가루의 첨가가 혼합쌀 가루의 열안정성에 약간의 도움을 준 것으로 판단된다. 일 반적으로 전분의 호화특성은 전분의 출처뿐만 아니라 전분 을 구성하고 있는 아밀로스와 아밀로펙틴의 함량과 비율에 따라 영향을 받게 된다. 따라서 본 연구에서 보여준 혼합쌀 가루의 호화특성은 쌀가루에 첨가된 쌀귀리 가루와 쌀가루 의 호화특성 차이뿐만 아니라 이들의 아밀로스 및 아밀로펙 틴 함량 차이에 기인하는 것으로 판단된다. 특히, 본 연구에 사용된 쌀가루가 아밀로스 함량이 $23.1 \%$ 인 멥쌀가루인 점 을 감안하면 쌀귀리 가루의 첨가량이 증가할수록 혼합쌀 가루의 아밀로스 함량은 감소하는 반면 아밀로펙틴 함량이 증가하여 수용액상에서 혼합쌀 가루가 쉽게 호화되어 호화 특성 값이 낮아지는 것으로 해석된다.

\section{쌀귀리 가루 첨가량에 따른 혼합쌀 가루 반죽의 물리적 특성}

쌀귀리 가루 첨가량별 혼합쌀 가루 반죽의 물리적 특성
을 조사한 결과는 Table 2 와 같다. 쌀가루 및 혼합쌀 가루 반죽의 $\mathrm{pH}$ 는 발효시간이 증가함에 따라 점차 감소하는 경 향을 보였으며, 발효 90 분까지는 쌀귀리 가루 첨가량에 상 관없이 $\mathrm{pH} 5.8$ 로 동일하였으나 발효 120 분에서 $10 \%$ 와 $15 \%$ 첨가군의 $\mathrm{pH}$ 가 5.8 로 $0 \%$ 와 $5 \%$ 첨가군보다 약간 높게 나타 났다. 반죽의 $\mathrm{pH}$ 는 발효를 위해 사용된 효모가 생산하는 유기산 함량에 의해 영향을 받으며, $\mathrm{pH} 5.0$ 이상에서는 반죽 의 $\mathrm{pH}$ 가 낮으면 발효속도가 빨라져 효모가 가스를 많이 생성하기 때문에 제빵적성이 좋은 것으로 알려져 있다(19).

혼합쌀 가루 반죽의 팽창률은 발효시간이 증가함에 따라 증가하는 경향이었으나, 반죽의 $\mathrm{pH}$ 와 달리 초기 30 분부터 $0 \%$ 첨가군이 $6.2 \%, 5 \%$ 첨가군이 $5.7 \%, 10 \%$ 첨가군이 $4.7 \%$, $15 \%$ 첨가군이 $4.3 \%$ 로 쌀귀리 가루 첨가량이 증가할수록 팽창률이 낮아져서 발효 120 분에서는 $15 \%$ 첨가군이 $0 \%$ 첨가군보다 $40.6 \%$ 감소하였다. 이는 시금치 분말을 첨가한 밀가루 반죽의 경우에도 비슷한 양상을 보여 본 연구결과와 유사하였다(16). 특히, 반죽이 팽창하는 것은 쌀가루 반죽 에 첨가된 활성글루텐과 건조효모에 의한 가스형성 때문으 로 반죽의 팽창률이 높을수록 제빵적성이 좋은 것으로 알려 져 있다(19). 결과적으로 5\% 첨가군은 반죽의 물리적 특성 에 크게 영향을 주지 않아서 쌀식빵 제조에 적용할 수 있을 것으로 기대되지만 $10 \%$ 이상의 과도한 첨가는 쌀식빵 제조 에 적용하기 어려울 것으로 판단된다.

\section{쌀귀리 가루 첨가량에 따른 쌀식빵의 품질특성}

쌀귀리 가루 첨가량별 혼합쌀 가루로 제조한 쌀식빵의 품질특성 결과는 Fig. 1 및 Table 3과 같다. 쌀귀리 가루 첨가량별 쌀식빵의 무게는 첨가량에 상관없이 약 443-444 $\mathrm{g}$ 으로 유의적 차이가 없었으나. 부피와 비용적도는 $10 \%$ 와 $15 \%$ 첨가군이 각각 $1,535 \mathrm{~mL}$ 와 $1,500 \mathrm{~mL}$ 및 3.5 와 3.4 로 $0 \%$ 와 $5 \%$ 첨가군(각각 $1,705 \mathrm{~mL}$ 와 $1,720 \mathrm{~mL}$ 및 3.8 과 3.9)보 다 감소하였으나, 굽기 손실률은 $10 \%$ 와 $15 \%$ 첨가군이 각 각 $11.7 \%$ 와 $11.5 \%$ 로 $0 \%$ 와 $5 \%$ 첨가군의 $11.4 \%$ 보다 증가하

Table 2. Physical properties of rice-naked oat composition flour dough during fermentation

\begin{tabular}{|c|c|c|c|c|c|}
\hline \multirow{2}{*}{ Physical property } & \multirow{2}{*}{$\begin{array}{l}\text { Fermentation time } \\
\text { (min) }\end{array}$} & \multicolumn{4}{|c|}{ Naked oat flour substitution (\%) } \\
\hline & & 0 & 5 & 10 & 15 \\
\hline \multirow{4}{*}{$\mathrm{pH}$} & 30 & $6.0 \pm 0.0^{\text {all }}$ & $6.0 \pm 0.0^{\mathrm{a}}$ & $6.0 \pm 0.0^{\mathrm{a}}$ & $6.0 \pm 0.0^{\mathrm{a}}$ \\
\hline & 60 & $5.9 \pm 0.1^{\mathrm{a}}$ & $5.9 \pm 0.0^{\mathrm{a}}$ & $5.9 \pm 0.0^{\mathrm{a}}$ & $5.9 \pm 0.0^{\mathrm{a}}$ \\
\hline & 90 & $5.8 \pm 0.0^{\mathrm{a}}$ & $5.8 \pm 0.0^{\mathrm{a}}$ & $5.8 \pm 0.0^{\mathrm{a}}$ & $5.8 \pm 0.0^{\mathrm{a}}$ \\
\hline & 120 & $5.7 \pm 0.0^{\mathrm{b}}$ & $5.7 \pm 0.0^{b}$ & $5.8 \pm 0.0^{\mathrm{a}}$ & $5.8 \pm 0.0^{\mathrm{a}}$ \\
\hline \multirow{4}{*}{$\begin{array}{c}\text { Expansion ratio } \\
(\%)\end{array}$} & 30 & $6.2 \pm 0.3^{\mathrm{a}}$ & $5.7 \pm 0.3^{\mathrm{a}}$ & $4.7 \pm 0.6^{b}$ & $4.3 \pm 0.6^{b}$ \\
\hline & 60 & $19.7 \pm 0.6^{\mathrm{a}}$ & $17.3 \pm 0.6^{b}$ & $15.7 \pm 0.6^{\mathrm{c}}$ & $15.3 \pm 0.3^{\mathrm{d}}$ \\
\hline & 90 & $29.8 \pm 0.3^{\mathrm{a}}$ & $22.7 \pm 0.6^{b}$ & $19.8 \pm 0.3^{\mathrm{c}}$ & $17.7 \pm 0.6^{\mathrm{d}}$ \\
\hline & 120 & $32.3 \pm 0.3^{\mathrm{a}}$ & $27.8 \pm 0.3^{b}$ & $22.7 \pm 0.6^{\mathrm{c}}$ & $19.2 \pm 0.3^{\mathrm{d}}$ \\
\hline
\end{tabular}

${ }^{1)}$ Values are mean \pm SD $(n=3)$. Different small letters ${ }^{(a-d)}$ in the same row are significantly different by Duncan's multiple test $(\mathrm{p}<0.05)$. 
Table 3. Baking property of rice bread manufactured with addition of naked oat flour

\begin{tabular}{|c|c|c|c|c|c|c|}
\hline & \multirow{2}{*}{\multicolumn{2}{|c|}{ Baking property }} & \multicolumn{4}{|c|}{ Naked oat flour substitution (\%) } \\
\hline & & & 0 & 5 & 10 & 15 \\
\hline \multirow{4}{*}{ Bread } & \multicolumn{2}{|c|}{ Weight (g) } & $444.0 \pm 1.4^{\mathrm{al})}$ & $443.8 \pm 1.5^{\mathrm{a}}$ & $442.5 \pm 1.0^{\mathrm{a}}$ & $443.8 \pm 1.0^{\mathrm{a}}$ \\
\hline & \multicolumn{2}{|c|}{ Volume (mL) } & $1,705.0 \pm 33.2^{\mathrm{a}}$ & $1,720.0 \pm 23.1^{\mathrm{a}}$ & $1,535.0 \pm 19.1^{\mathrm{b}}$ & $1,500.0 \pm 16.3^{b}$ \\
\hline & \multicolumn{2}{|c|}{ Specific volume (mL/g) } & $3.8 \pm 0.1^{\mathrm{b}}$ & $3.9 \pm 0.0^{\mathrm{a}}$ & $3.5 \pm 0.0^{\mathrm{b}}$ & $3.4 \pm 0.0^{\mathrm{c}}$ \\
\hline & \multicolumn{2}{|c|}{ Baking loss ratio $(\%)$} & $11.4 \pm 0.3^{\mathrm{a}}$ & $11.4 \pm 0.3^{\mathrm{a}}$ & $11.7 \pm 0.2^{\mathrm{b}}$ & $11.5 \pm 0.2^{b}$ \\
\hline \multirow{8}{*}{ Crumb } & \multirow{3}{*}{ Color } & $\mathrm{L}$ & $85.3 \pm 0.9^{\mathrm{a}}$ & $81.8 \pm 0.6^{b}$ & $79.5 \pm 1.1^{\mathrm{c}}$ & $77.0 \pm 0.8^{d}$ \\
\hline & & a & $0.9 \pm 0.1^{\mathrm{c}}$ & $1.5 \pm 0.1^{\mathrm{b}}$ & $2.2 \pm 0.2^{\mathrm{a}}$ & $2.5 \pm 0.1^{\mathrm{a}}$ \\
\hline & & $\mathrm{b}$ & $20.1 \pm 0.5^{\mathrm{c}}$ & $22.0 \pm 0.4^{b}$ & $23.9 \pm 0.9^{a}$ & $24.0 \pm 0.9^{\mathrm{a}}$ \\
\hline & \multirow{5}{*}{$\begin{array}{l}\text { Texture } \\
\text { profile } \\
\text { analysis }\end{array}$} & Hardness (g) & $220.5 \pm 11.6^{\mathrm{c}}$ & $235.0 \pm 14.0^{c}$ & $425.0 \pm 21.4^{\mathrm{b}}$ & $491.9 \pm 19.6^{\mathrm{a}}$ \\
\hline & & Cohesiveness & $0.6 \pm 0.0^{\mathrm{a}}$ & $0.6 \pm 0.0^{\mathrm{a}}$ & $0.6 \pm 0.0^{\mathrm{a}}$ & $0.6 \pm 0.0^{\mathrm{a}}$ \\
\hline & & Springiness & $0.9 \pm 0.0^{\mathrm{a}}$ & $0.9 \pm 0.0^{\mathrm{a}}$ & $0.9 \pm 0.0^{\mathrm{a}}$ & $0.9 \pm 0.0^{\mathrm{a}}$ \\
\hline & & Gumminess (g) & $135.2 \pm 2.3^{\mathrm{c}}$ & $135.8 \pm 8.8^{c}$ & $240.5 \pm 12.6^{b}$ & $277.4 \pm 9.8^{\mathrm{a}}$ \\
\hline & & Chewiness (g) & $123.1 \pm 3.0^{c}$ & $119.7 \pm 9.3^{c}$ & $217.3 \pm 11.6^{b}$ & $248.9 \pm 7.2^{\mathrm{a}}$ \\
\hline
\end{tabular}

${ }^{1)}$ Values are mean $\pm S D$ ( $n=3$ and/or $n=5$ for texture profile analysis). Different small letters ${ }^{(a-d)}$ in the same row are significantly different by Duncan's multiple test ( $p<0.05$ ).

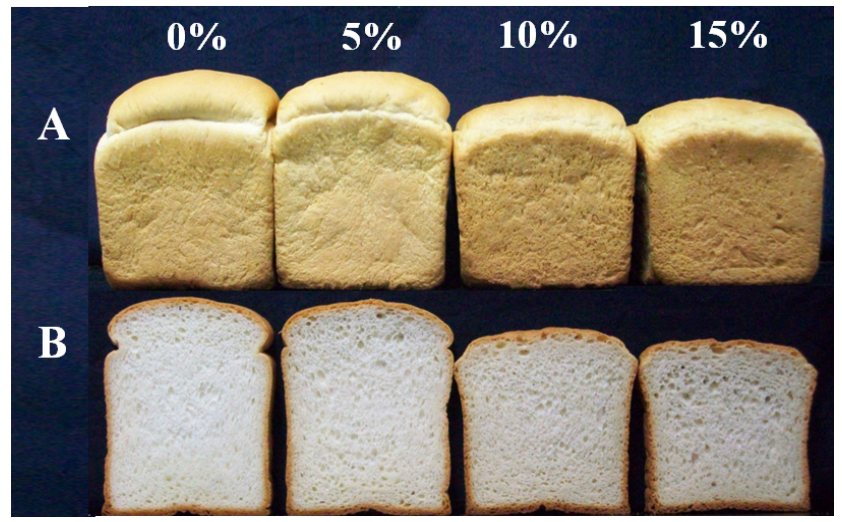

Fig. 1. Picture of rice bread (A) and crumb (B) manufactured with addition of naked oat flour.

였다. 이와 같은 부피의 감소 및 굽기 손실률의 증가 현상은 반죽 내에 글루텐 함량이 부족하여 발효 중에 생성되는 가스를 보유할 수 있는 능력이 떨어지기 때문으로 판단된 다. 또한, 귀리에 함유되어 있는 수용성 $\beta$-glucan이 물과 강한 친화성을 가지기 때문에 전분과 결합할 수 있는 물이 부족하게 되어 결과적으로 baking 과정에 수분의 증기압이 낮아져 팽화가 잘 되지 않고 부피가 감소하게 된다(20). 특히, 쌀가루는 밀가루와 달리 글루텐을 함유하고 있지 않 기 때문에 따로 글루텐을 첨가해야만 반죽의 부피가 형성되 며, baking 이후에도 형성된 부피를 유지해야 한다(21). 본 연구에서는 $5 \%$ 첨가군까지는 외적으로 대조군과 크게 차 이를 보이지 않았으며, 결과적으로 쌀식빵의 제빵적성에 영향을 주지 않을 것으로 판단된다.

쌀귀리 가루 첨가량별 쌀식빵 속질의 색도는 쌀귀리 가 루 첨가량이 증가할수록 $\mathrm{L}$ 값이 85.3 에서 $77.0, \mathrm{a}$ 값이 0.9 에
서 $2.5, \mathrm{~b}$ 값이 20.1 에서 24.0 로 $\mathrm{L}$ 값은 감소하였으나 $\mathrm{a}$ 와 $\mathrm{b}$ 값이 증가하여 쌀식빵에 쌀귀리 가루가 첨가되면서 약간 어두워지는 경향을 보였다. 이는 쌀식빵의 제조를 위해 첨 가된 쌀귀리 가루가 가지고 있는 색도에 의한 영향을 받은 것으로 판단된다.

쌀귀리 가루 첨가량별 쌀식빵 속질의 조직감을 측정한 결과, 경도는 쌀귀리 가루 첨가량이 증가할수록 $220.5 \mathrm{~g}$ 에 서 $491.9 \mathrm{~g}$ 으로 크게 증가하였으나 응집성과 탄력성은 쌀귀 리 가루 첨가량에 상관없이 각각 0.6 과 0.9 로 변화가 없었다. 검성과 씹힘성은 $0 \%$ 와 $5 \%$ 첨가군에서 각각 135.2 와 135.8 및 123.1 과 119.7 로 유사하였으나 $10 \%$ 와 $15 \%$ 첨가군에서 각각 240.5와 277.4 및 217.3과 248.9로 높게 나타났다. 특히, 식빵의 부피와 속질의 기공 발달정도 등이 식빵의 경도에 영향을 주는 것으로 알려져 있는데(19), 본 연구결과 나타난 $0 \%$ 첨가군의 속질은 부피가 크고 기공이 작아 잘 보이지 않았으나, $15 \%$ 첨가군의 속질은 부피가 작은 반면에 기공 의 크기가 크고 개수가 많이 관찰되었다(Fig. 1). Ha 등(22) 은 보릿가루를 대체한 밀가루식빵의 조직감 측정에서 보릿 가루 첨가량이 증가할수록 부피가 작아지며 경도가 증가하 지만, 탄성, 응집성, 검성 등은 $10 \%$ 첨가군까지는 유의적 차이가 없었으나 $20 \%$ 첨가군부터 증가하였다고 보고하여 본 연구결과와 비슷한 경향을 나타내었다.

\section{요 약}

쌀가루에 쌀귀리 가루를 혼합한 혼합쌀 가루로 제조한 쌀식빵의 품질특성을 조사하였다. 쌀귀리 가루 첨가량이 증가할수록 수분을 제외한 일반성분과 $\beta$-glucan 함량은 증 
가한 반면에 전분과 관련된 성분은 감소하는 것으로 나타났 다. 쌀가루의 호화특성은 쌀귀리 가루 첨가량이 $5 \%$ 에서 $15 \%$ 까지 증가함에 따라 혼합쌀 가루의 최고점도, 최저점 도, 최종점도 및 치반점도는 소폭 감소하는 경향을 나타내 었다. 쌀귀리 가루 첨가량별 혼합쌀 가루 반죽은 발효시간 이 증가함에 따라 반죽의 $\mathrm{pH}$ 는 감소하였으나 반죽의 팽창 률은 증가하였으며, 특히 쌀귀리 가루 첨가량이 증가할수 록 팽창률이 낮아졌다. 쌀식빵의 부피와 비용적도 및 굽기 손실률은 $10 \%$ 와 $15 \%$ 첨가군이 $0 \%$ 와 $5 \%$ 첨가군보다 낮았 다. 쌀귀리 가루 첨가량별 쌀식빵 속질의 색도는 쌀귀리 가루 첨가량이 증가할수록 $\mathrm{L}$ 값은 감소하였으나 $\mathrm{a}$ 와 $\mathrm{b}$ 값이 증가하였다. 혼합쌀 가루로 제조한 쌀식빵의 품질특성 결 과, 쌀귀리 가루 첨가량이 증가할수록 쌀식빵의 경도는 증 가하였으나, 응집성과 탄성은 쌀귀리 가루 첨가량에 상관 없이 유의적 차이를 보이지 않았다. 검성과 씹힘성은 $0 \%$ 와 $5 \%$ 첨가군에서는 유사하였으나 $10 \%$ 와 $15 \%$ 첨가군에서는 높게 나타났다. 결과적으로 쌀귀리 가루를 첨가한 쌀식빵 제조 시 쌀귀리 가루 5\% 첨가군이 가장 좋은 품질특성을 나타내었다.

\section{References}

1. Han OK, Park HH, Park TI, Seo JH, Park KH, Kim JG, Heo HY, Hong YG, Kim DH (2008) A new early-heading and high-yielding naked oat cultivar for human consumption, 'Choyang'. Korean J Breed Sci, 40, 512-516

2. Singh R, De S, Belkheir A (2013) Avena sativa (Oat), a potential neutraceutical and therapeutic agent: an overview. Crit Rev Food Sci Nutr, 53, 126-144

3. Wang Q, Ellis PR (2014) Oat B-glucan: physicochemical characteristics in relation to its blood-glucose and cholesterol-lowering properties. Br J Nutr, 112, S4-S13

4. Whitehead A, Beck EJ, Tosh S, Wolever TM (2014) Cholesterol-lowering effects of oat $\beta$-glucan: a metaanalysis of randomized controlled trials. Am J Clin Nutr, 100, 1413-1421

5. Lee MJ, Park SY, Kim YK, Kim HS, Park HH, Lee YJ, Jeong HS (2017) Physicochemical properties and $\beta$ -glucan contents of Korean naked oat (Avena sativa L.) cultivars. Korean J Food Sci Technol, 49, 97-103

6. Biel W, Bobko K, Maciorowski R (2009) Chemical composition and nutritive value of husked and naked oats grain. J Cereal Sci, 49, 413-418

7. Sterna V, Zute S, Brunava L (2016) Oat grain composition and its nutrition benefice. Agric Agric Sci Procedia, 8, 252-256

8. AOAC (1996) Official Methods of Analysis. $15^{\text {th }}$ ed, Association of Official Analytical Chemists, Washington DC, USA, p 1121-1180

9. McCleary BV, Solah V, Gibson TS (1994) Quantitative measurement of total starch in cereal flours and products. J Cereal Sci, 20, 51-58

10. Brand-Williams W, Cuvelier ME, Berset C (1995) Use of a free radical method to evaluate antioxidant activity. LWT-Food Sci Technol, 28, 25-30

11. Boyaci IH, Williams PC, Koksel H (2004) A rapid method for the estimation of damaged starch in wheat flour. J Cereal Sci, 39, 139-145

12. Prosky L, Asp NG, Schweizer TF, DeVries JW, Furda I (1998) Determination of insoluble, soluble, and total dietary fiber in foods and food products. Interlaboratory study. J Assoc Off Anal Chem, 71, 1017-1023

13. McClear BV, Glennie-Holmes M (1985) Enzymic quantification of $(1 \rightarrow 3)(1 \rightarrow 4)-\beta$-D-glucan in barley and malt. J Inst Brew, 91, 285-295

14. Jun HI, Yoo SH, Song GS, Kim YS (2017) Effect of particle size of naked oat flours on physicochemical and antioxidant property. Korean J Food Preserv, 24, 965-974

15. Kim CH, Tie J, Ryu GH (2012) Effect of moisture content on physical properties of extruded cereal flours. J Korean Soc Food Sci Nutr, 41, 1603-1610

16. Ko SH, Bing DJ, Chun SS (2013) Quality characteristics of white bread manufactured with Shinna Seomcho (Spinacia oleracea L.) powder. J Korean Soc Food Sci Nutr, 42, 766-773

17. SAS (2004) SAS/STAT 9.1 User's Guide. SAS Institute Inc, Cary, NC, USA, p 421-480

18. Lee NY (2013) Starch and quality characteristic of Korean rice cultivar with waxy and non-waxy type. Korean J Crop Sci, 58, 226-231

19. Bae JH, Woo HS, Choi HJ, Choi C (2003) Physicochemical properties of onion powder added wheat flour dough. Korean J Food Sci Technol, 35, 436-441

20. Gill S, Vasanthan T, Ooraikul B, Rossnagel B (2002) Wheat bread quality as influenced by the substitution of waxy and regular barley flours in their native and extruded forms. J Cereal Sci, 36, 219-237

21. Park MJ, Lee KH, Kang SA (2006) Effect of particle size of rice flour on poping rice bread. Korean J Food Cookery Sci, 22, 419-427

22. Ha DM, Park YK, Kang JH, Kim MH (2012) Dough properties and quality characteristics of breads added with barley flour. Korean J Food Preserv, 19, 344-353 